\title{
EFEK ANTIDEPRESAN KOMBINASI INFUSA BIJI PALA (Myristica fragrans) DAN DAUN KEMANGI (Ocimum basilicum) PADA MENCIT JANTAN PUTIH (Mus musculus)
}

\author{
Endang Istriningsih ${ }^{1}$, Khoirunnisa ${ }^{2}$, Devi Ika K.S ${ }^{3}$ \\ e-mail : endang.hanggoro@gmail.com \\ S1 Farmasi Sekolah Tinggi Ilmu Kesehatan Bhakti Mandala Husada Slawi \\ Jl. Cut Nyak Dhien No 16 Kalisapu, Slawi Telp/Fax (0283)6197571/6198450
}

\begin{abstract}
Abstrak
Depresi adalah keadaan murung setiap orang yang mengalami kekecewaan hebat atau kehilangan pribadi dengan sendirinya menjadi murung. Pada penelitian telah terbukti bahwa biiji pala mengandung senyawa miristin dan daun kemangi mengandung senyawa eugenol yang mempunyai efek antidepresan. Tujuan penelitian ini yaitu untuk mengetahui efek antidepresan kombinasi infusa biji pala dan daun kemangi serta mengetahui konsentrasi kombinasi yang paling baik pada mencit putih jantan. Biji pala dan daun kemangi diekstraksi dengan metode infusa. Dosis biji pala yang digunakan $10 \mathrm{mg} / \mathrm{KgBB}$ dan daun kemangi $1,5 \mathrm{~g} / \mathrm{KgBB}$ dikombinasi dengan konsentrasi (1:1), konsentrasi (1:5) dan konsentrasi (5:1). Kontrol negatif menggunakan akuades dan kontrol positif menggunakan amitriptilin. Pengujian antidepresan pada mencit putih jantan menggunakan metode forced swimming test yang dilakukan selama 10 hari dengan durasi setiap harinya 8 menit, pada hari ke-11 dilakukan pemberian obat dan diukur waktu imobilitasnya. Data pengujian antidepresan dianalisis menggunakan metode kruskalwallis dan mann-whitney. Hasil waktu imobilitas perbandingan infusa biji pala dan daun kemangi (1:1) lebih singkat dibandingkan dengan perbandingan lainnya. Semakin singkat waktu imobilitas maka semakin baik daya antidepresannya. Pada uji kruskal-wallis menunjukan ada perbedaan bermakna dengan nilai signifikan 0,003<0,05 sehingga dilanjutkan uji mann-whitney. Pada uji mann-whitney P3 dengan Kdan $\mathrm{K}+$ dengan $\mathrm{P} 1$ menunjukan adanya perbedaan pada setiap kelompoknya.
\end{abstract}

Kata kunci: Depresi, Biji Pala, Daun Kemangi, Antidepresan.

\section{Pendahuluan}

Depresi merupakan salah satu masalah kesehatan jiwa di dunia, termasuk Indonesia. WHO melaporkan terdapat sekitar 35 juta orang di dunia menderita depresi ${ }^{[1]}$. Prevalensi gangguan mental emosional dengan gejala - gejala depresi dan kecemasan untuk usia 15 tahun keatas mencapai 14 juta orang atau $6 \%$ dari jumlah penduduk Indonesia ${ }^{[2]}$. Kejadian depresi pada wanita 2 sampai 3 kali lebih sering dibandingkan pria. Depresi terjadi pada setaip umur berkisar umur 25-44 tahun ${ }^{[3]}$.

Dilihat dari sisi biologiknya, depresi melibatkkan adanya gangguan pada neurotransmitter norefinefrin, serotonin dan dopamin . Neurotransmiter neurotransmiter tersebut yang menjadi target antidepresan. Pada umumnya obat antidepresan dibagi menjadi empat kelompok besar seperti selective serotonin re-uptake inhibitors (SSRIs), serotoninnorepinephrine reuptake inhibitors (SNRIs), tricyclic adtidepressants (TCAs), mixed serotonergic effects (mixed 5-HT), serotonin and a2adrenergic antagonist dan monoamine oxidase inhibitor (MAOIs)

Obat-obat tersebut menimbulkan efek samping seperti hipotensi, kejang, sedatif, mulut kering, mual dan muntah ${ }^{[4]}$ Untuk mengindari efek samping tersebut maka digunakan alternatif bahan alam antidepresan yaitu biji pala dan daun kemangi. Kandungan senyawa kimia biji pala yang dapat memberikan efek antidepresan yaitu miristisin. Miristisin memiliki mekanisme kerja dengan menghambat enzim Mono Amine Oxidase (MAO). Pada daun kemangi kandungan eugenol dapat menghambat enzim Mono Amine Oksidase A dan B ${ }^{[5]}$.

\section{Metode Penelitian}

Penelitian ini menggunakan jenis penelitian eksperimental dengan post test randomized controlled group design yaitu 
membandingkan kelompok uji dengan kelompok kontrol. Alat-alat yang digunakan pada penelitian ini antara lain timbangan analitik, spuit sonde (0,1-1 ml), kain flanel, batang pengaduk, beaker glass, objek glass, tabung reaksi, oven, corong dan akuarium silinder dengan tinggi $25 \mathrm{~cm}$ dan berdiameter $10 \mathrm{~cm}$. Bahan yang digunakan pada penelitian ini adalah biji pala (Myristica fragrans) dan daun kemangi (Ocimum basilicum). Bahan lain yang digunakan akuades, etanol $70 \%$, reagen mayer, $\mathrm{NaOH}$ dan $\mathrm{HCl}$. Hewan uji yang digunakan adalah mencit putih jantan. Masing-masing kelompok uji terdiri dari 5 ekor mencit putih jantan.

a. Prosedur Penelitian

Determinasi dilakukan di Laboratorium Biologi Farmasi Sekolah Tinggi Ilmu Kesehatan Bhakti Mandala Husada Slawi. Tanaman segar, dideterminasi mulai dari akar, batang, daun, bunga dan biji.Untuk mengetahui jenis spesies dari tanamannya.

Sampel simplisia biji pala (Myristica fragrans) dan daun kemangi (Ocimum basilicum) yang telah didapat dicuci dengan bersih, hal ini bertujuan supaya sampel bebas dari kotoran yang masih melekat, setelah itu dirajang sesuai ukuran yang dikehendaki dan dilakukan pengeringan menggunakan sinar matahari langsung. ${ }^{[6]}$.

b. Pembuatan Ekstrak Metode Infusa

Serbuk sampel sebanyak 500 gram dan dimasukkan dalam panci A ditambah $100 \mathrm{ml}$ air. Tumpuk panci A pada panci $B$ yang telah mendidih. Pada panci B banyaknya air secukupnya hingga sebagian panci A terendam dengan temperatur terukur $90^{\circ} \mathrm{C}$ selama 15 menit

c. Uji Organoleptik

Ekstrak yang telah diperoleh diamati bentuk, bau, warna, dan rasa ${ }^{[6]}$.

d. Uji Alkaloid

Infusa 0,5 gram dalam tabung reaksi ditambahkan $2 \mathrm{ml}$ etanol $70 \%$ kemudian diaduk, ditambahkan $5 \mathrm{ml}$ $\mathrm{HCl} 2 \mathrm{~N}$, dipanaskan pada penangas air. Setelah dingin, campuran disaring dan filtrat ditambahkan beberapa tetes reagen Mayer. Sampel kemudian diamati hingga keruh atau ada endapan yang menunjukkan hasil positif mengandung alkaloid ${ }^{[7]}$.

e. Uji Saponin

Infusa $2 \mathrm{ml}$ dalam tabung reaksi, ditambah $10 \mathrm{ml}$ akuades dan gojog 30 menit. Jika terjadi busa maka sampel mengandung saponin ${ }^{[8]}$.

f. Uji Flavonoid

Infusa $2 \mathrm{ml}$ dalam tabung reaksi ditambah beberapa tetes $\mathrm{NaOH}$, jika warnanya menjadi pekat maka menunjukan adanya flavonoid. Hasil ditambahkan dengan $\mathrm{HCl}$ warna akan kembali seperti semula ${ }^{[9]}$.

g. Uji Minyak Atsiri

Infusa dimasukkan diuapkan dalam cawan penguap, jika berbau aromatik atau menyenangkan maka hal itu menunjukkan adanya senyawa golongan minyak atsiri miristin dan eugenol.

h. Penentuan Dosis

Dosis daun kemangi yang digunakan dalam penelitian adalah 0,0039 $\mathrm{mg} / \mathrm{gBB}$ mencit. Dosis daun pala yang digunakan adalah $0,000026 \mathrm{mg} / \mathrm{gBB}$ mencit. Dan dosis amitriptillin yang digunakan adalah $0,000065 \mathrm{mg} / \mathrm{gBB}$ mencit

i. Pemberian Infusa

Mencit dibagi menjadi 5 kelompok secara acak (kelompok kontrol negatif, kelompok kontrol positif dan 3 kelompok uji). Membuat mencit depresi dengan metode forced swimming test dengan durasi 8 menit selama 10 hari, pada hari ke-11 diperlakuan pada kontrol negatif disuntikkan aquadest secara oral, kelompok kontrol positif dengan amitriptilin, pada kelompok uji menggunakan kombinasi infusa biji pala dan daun kemangi dengan konsentrasi (1:1), konsentrasi (1:5) dan konsentrasi (5:1). Setelah mencit mendapatkan perlakuan diamkan selama 1 jam dan masukan kedalam bejana yang berisi air dan dibiarkan berenang selama 8 menit, pengukuran waktu imobilitas dilakukan pada 6 menit terakhir ${ }^{[10]}$. 


\section{Hasil dan pembahasan}

Penelitian ini bertujuan untuk mengetahui efek antidepresan dari kombinasi infusa biji pala (Myristica fragrans) dan daun kemangi (Ocimum basilicum) pada mencit putih jantan galur wistar, serta untuk mengetahui pada konsentrasi berapa kombinasi infusa biji pala (Myristica fragrans) dan daun kemangi (Ocimum basilicum) yang paling baik dalam memberikan efek antidepresan. Parameter yang digunakan untuk mengukur depresi dengan melihat waktu imobilitas, dimana mencit bergerak pasif pada kolam silinder yang berisi air. Waktu imobilitas lalu dianalisis mengunakan SPSS, semakin tinggi waktu imobilitas maka semakin rendah efek antidepresan.

Penggunaan kombinasi biji pala dan daun kemangi karena mekanisme kerjanya yang sama-sama menghambat enzim Mono Amin Oksidasi [11]. Monoamin Oksidase merupakan suatu sistem enzim kompleks yang terdistribusi luas dalam tubuh, berperan dalam dekomposisi amin biogenik, seperti norepinefrin, epinefrin, dopamin, serotonin.

a. Uji Organoleptik

Setelah diperoleh infusa biji pala dan daun kemangi selanjutnya dilakukan uji secara organoleptik untuk mengetahui warna, bau dan rasa.

Tabel 1. Hasil Uji Organoleptik

\begin{tabular}{ccc}
\hline $\begin{array}{c}\text { Uji } \\
\text { Organoleptik }\end{array}$ & $\begin{array}{c}\text { Infusa Biji } \\
\text { Pala }\end{array}$ & $\begin{array}{c}\text { Infusa Daun } \\
\text { Kemnagi }\end{array}$ \\
\hline Warna & Coklat terang & Coklat pekat \\
Bau & Khas & Khas aromatik \\
& aromatik pala & kemangi \\
Rasa & Kelat, agak & Kelat, agak \\
& sedikit pedas & sedikit pahit \\
\hline
\end{tabular}

b. Skrining Fitokimia

Tujuan skrining fitokimia untuk mengetahui kandungan apa saja yang terdapat pada infusa biji pala dan daun kemangi.

Tabel 2. Hasil Uji Skrining Fitokimia Infusa Biji pala dan daun kemangi

\begin{tabular}{ccc}
\hline Skrining & \multicolumn{2}{c}{ Tanaman } \\
\cline { 2 - 3 } Fitokimia & Biji Pala & $\begin{array}{c}\text { Daun } \\
\text { Kemangi }\end{array}$ \\
\hline Uji Alkaloid & $(+)$ & $(+)$ \\
& Terbentuknya & Terbentuknya
\end{tabular}

Uji Saponin

Uji

Flavonoid

$$
\begin{aligned}
& \text { warna putih } \\
& \text { keruh }
\end{aligned}
$$

$(+)$

Terbentuknya

busa

$(+)$

Warna kembali seperti semula

$(+)$

Uji Minyak Atsiri Bau aromatik warna kuning keruh

$(+)$

Terbentuknya

busa

$(+)$

Warna

kembali

seperti

semula

(+)

Bau aromatik c. Pengukuran waktu imobilitas

Mencit putih jantan diadaptasi selama 2 minggu dibuat depresi dengan metode forced swimming test selama 10 hari dengan durasi 8 menit dan tidak diukur waktu imobilitasnya. Perlakuan ini bertujuan untuk membuat mencit depresi, kemudian pada hari ke-11 mencit diberikan amitriptilin, akuades, kombinasi infusa biji pala dan infusa daun kemangi konsentrasi (1:1), konsentrasi (1:5) dan konsentrasi (5:1), kemudian dilakukan uji forced swimming test selama 8 menit dan pengukuran waktu imobilitas pada 6 menit terakhir [10].

Hasil penelitian setiap hewan uji mempunyai waktu imobilitas yang berbeda-beda dalam satu kelompok. Perbedaan tersebut disebabkan karena tiap individu mempunyai kemampuan yang berbeda dalam menanggapi depresi, sama halnya dengan manusia. Pada penelitian ini hewan uji dianggap telah depresi pada saat hewan uji menunjukan perilaku diam mengapung didalam kolam, yang diukur dengan parameternya yang disebut waktu imobilitas

Data waktu imobilitas yang diperoleh dianalisis menggunakan SPSS untuk menentukkan uji hipotesis yang sesuai dilakukan terlebih dahulu uji normalitas dan uji homogenitas. Dari hasil uji normalitas data waktu imobilitas tersebut menunjukkan semua terdistribusi normal dilihat dari nilai signifikan 0,097-0,942, nilai tersebut $>0,05$. Dari hasil uji homogenitas data waktu imobilitas ternyata tidak homogen dilihat dari nilai signifikan $0,013<0,005$. 
Oleh karena itu digunakan uji hipotesis non parametrik kruskal-wallis. Dari hasil uji kruskal-wallis didapatkan nilai signifikan 0,003 nilai tersebut >0,05. Oleh karena itu dilanjut dengan uji mann-whitney untuk melihat perbedaan antar kelompok perlakuan. Hasil pengukuran waktu imobilitas dapat dilihat sebagai berikut :

Tabel 3. Rerata dan Standar Devisiasi

Waktu Imobilitas

\begin{tabular}{cccc}
$\begin{array}{c}\text { Kelompok } \\
\text { (biji pala:daun } \\
\text { kemangi)) }\end{array}$ & Mean & Median \pm & Signifikan \\
& & SD (detik) & $(=\mathrm{P})$ \\
\hline P1(1:1) & 46,4 & $24,0 \pm 4,26$ & \\
P2(1:5) & 75,0 & $68,0 \pm 3,38$ & \\
P3(5:1) & 87,8 & $93,0 \pm 1,24$ & 0,003 \\
K-(kontrol -) & 146 & $140 \pm 4,65$ & \\
K+(kontrol +) & 114 & $114 \pm 1,01$ & \\
\hline
\end{tabular}

Hasil penelitian ini menunjukan terdapat perbedaan bermakna antara kelompok P3 (kombinasi infusa biji pala dan daun kemangi 5:1) dengan kelompok K- (akuades) dan kelompok P1 (kombinasi infusa biji pala dan daun kemangi 1:1) dengan kelompok $\mathrm{K}+$ (amitriptillin) dengan nilai signifikan $\mathrm{p}=0,009(<0,05)$.

Hasil penelitian tersebut menunjukkan bahwa kombinasi infusa biji pala dan infusa daun kemangi memiliki aktifitas sebagai antidepresan dengan kombinasi yang paling baik dari urutan konsentrasi (1:1), (1:5) dan konsentrasi (5:1) jika dibandingkan dengan hewan uji yang hanya diberikan akuades. Namun pada kontrol positif pemberian amitriptilin memiliki waktu imobilitas lebih panjang daripada kelompok perlakuak pemberian kombinasi infusa biji pala dan daun kemangi, hal ini dikarenakan obat antidepresan amitriptilin dapat memberikan efek antidepresan setelah penggunaan 2-3 minggu ${ }^{[12]}$.

Biji pala memiliki aktifitas antidepresan terbesar adalah 10 $\mathrm{mg} / \mathrm{kgBB}$ dalam penelitian yang berjudul antidepressant-like activity of n-hexane extract of nutmeg (myristica fragrans) seeds in mice ${ }^{[13] .}$

Daun kemangi memiliki aktifitas antidepresan terbesar adalah 1,5 $\mathrm{mg} / \mathrm{kgBB}$ dalam penelitian yang berjudul antidepressant-like activities of ocimum basilicum (sweet basil) in the forced swimming test of rats exposed to electromagnetic field (emf) [14]. Perbedaan dari penelitian ini dengan penelitian sebelumnya adalah penelitian ini dilakukan kombinasi antara biji pala dan daun kemangi, serta pembutannya dengan metode infusa.

Senyawa aktif yang berperan sebagai antidepresan pada biji pala adalah miristisin. Miristisin memiliki mekanisme kerja dengan menghambat enzim Mono Amine Oxidase (MAO) ${ }^{[15]}$. Kandungan eugenol daun kemangi mempunyai mekanisme kerja dengan menghambat enzim mitokondrial yang terdapat dalam dua bentuk utama A dan B. Peran utama MAO adalah mengoksidasi senyawa-senyawa monoamin, termasuk norepinefrin, serotonin dan dopamin. Memblokir enzim degradatif ini, penghilangan transmiter-transmiter tersebut dapat diperlambat ${ }^{[16]}$. Kadar MAO dihambat oleh miristin dan eugenol, maka oksidasi serotonin akan menurun dan memberikan efek antidepresan.

\section{Kesimpulan}

Berdasarkan hasil penelitian dari kombinasi infusa biji pala dan daun kemangi dapat disimpulkan bahwa Kombinasi infusa biji pala dan daun kemangi dapat memberikan efek antidepresan pada mencit putih jantan dan kombinasi infusa biji pala dan daun kemangi yang paling baik memberikan efek antidepresan pada konsentrasi (1:1).

\section{Daftar Pustaka}

[1] WHO (2016) Depression and Other Common Mental Disorders: Global Health Estimates. Geneva: the WHO Document Production Service.

[2] Riset Kesehatan Dasar(Riskesdas). (2013). Badan Penelitian dan Pengembangan Kesehatan Kementerian 
RI tahun 2013.Diakses: 19 Oktober 2014, dari http://www.depkes.go.id/resources/dow nload/general/Hasil\%20Riskesdas\%20 2013.pdf

[3] Ikawati, Z.(2011) Farmakoterapi Penyakit Sistem Syaraf Pusat.

Yogyakarta: Bursa Ilmu

[4] Dipiro, et al., (2017)Pharmacotherapy: A Pathophysiologic Approach. Mc Graw Hill Education.

[5] Irie, Y.(2006) Effects of eugenol on central nervous system: its possible application to treatment of alzheimer's disease, depression, and parkinson's disease current bioactive compounds. Bioorganic and Medicinal Chemistry, Vol 2(10), 57-66.

[6] Anonim. (2000). Parameter Standar Umum Ekstrak Tumbuhan

Obat. Jakarta: Departemen Kesehatan RI.

[7] Mojab,F., dkk. (2003). Phytochemical Screaning of Some Spesies of Irania Plants. Iranian of Journal Pharmaceutical Research, Vol 2(2), 77-82.

[8] Anonim. (1980). Materia Medika Indonesia Jilid IV.Jakarta:Departemen Kesehatan RI.

[9] Emmanuel, dkk. (2013). Phytochemical screening, chemical composition and antimicrobial activity of Zingiber officinale essential oil of Adamaoua region (Cameroon). J. Chem. Pharm. Res., Vol 5(7):296-301

[10] Swati, dkk. (2013). Evaluation of Antidepressant Activity of Eclipta Alba Using Animal Models. Asian J Pharm Clin res Vol(6)3, 118-120.

[11] Adelina, R. (2013). Kajian Tanaman Obat Indonesia yang Berpotensi sebagai Antidepresan. Jurnal Kefarmasian: Pusat Biomedis dan Teknologi Dasar Kesehatan, Badan Litbang Kesehatan, Kementrian Kesehatan RI, Vol 3(1), 9-18.

[12] Anonim. (2009). Farmakologi dan Terapi Edisi $5 . \quad$ Jakarta Departemen Kesehatan RI

[13]Dhingra D. \& Sharma A. (2006). Antidepresant Like Activity of n-
Hexane Seeds in Mice. Journal Meed Food, Vol 9(1), 9-89.

[14] Abdoly., dkk. (2012). Antidepressantlike activities of Ocimumbasilicum(sweet Basil) in the forced swimming test of ratsexposed to electromagnetic field (EMF). African Journal of Pharmacy and Pharmacology, Vol 6(3), 211-215.

[15] Sanggalli, B.C. (2000). Toxicology of Nutmeg Abuse. Clinical Toxicology, Vol 38(6), 8-671.

[16] Stringer, J.L. (2016). Konesp Dasar Farmakologi Panduan Untuk Mahasiswa Edisi 3. (Huriawati Hartono, Jully Manurang Penerjemah). Jakarta: EGC. 